State Ideology and Language in Tanzania 



\section{State Ideology and Language in Tanzania}

Second and Revised Edition

\section{Jan Blommaert}


(C) Jan Blommaert, 1999, 2014

Edinburgh University Press Ltd

The Tun - Holyrood Road

12(2f) Jackson's Entry

Edinburgh EH8 8PJ

www.euppublishing.com

First edition published by Rudiger Koeppe in 1999.

Typeset in 10/12pt Adobe Garamond by Servis Filmsetting Ltd, Stockport, Cheshire, and printed and bound in Great Britain by CPI Group (UK) Ltd, Croydon CR0 4YY

A CIP record for this book is available from the British Library

ISBN 9780748675791 (hardback)

ISBN 9780748675814 (webready PDF)

ISBN 9780748675807 (paperback)

ISBN 9780748675838 (epub)

The right of Jan Blommaert to be identified as Author of this work has been asserted in accordance with the Copyright, Designs and Patents Act 1988, and the Copyright and Related Rights Regulations 2003 (SI No. 2498). 